\title{
Isolation and Characterization of Bacteriophage ZCSE6 against Salmonella spp.: Phage Application in Milk
}

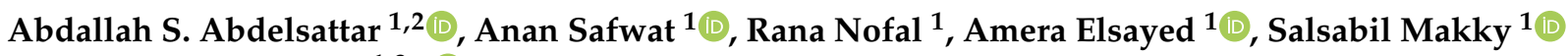 \\ and Ayman El-Shibiny 1,3,*(D) \\ 1 Center for Microbiology and Phage Therapy, Zewail City of Science and Technology, October Gardens, \\ 6th of October City, Giza 12578, Egypt; p-abdallah.abdelsattar@zewailcity.edu.eg (A.S.A.); \\ agaber@zewailcity.edu.eg (A.S.); p-rnofal@zewailcity.edu.eg (R.N.); s-ameraelsayed@zewailcity.edu.eg (A.E.); \\ syoussef@zewailcity.edu.eg (S.M.) \\ 2 Center for X-ray and Determination of Structure of Matter, Zewail City of Science and Technology, \\ October Gardens, 6th of October City, Giza 12578, Egypt \\ 3 Faculty of Environmental Agricultural Sciences, Arish University, Arish 45511, Egypt \\ * Correspondence: aelshibiny@zewailcity.edu.eg
}

Citation: Abdelsattar, A.S.; Safwat, A.; Nofal, R.; Elsayed, A.; Makky, S.; El-Shibiny, A. Isolation and Characterization of Bacteriophage ZCSE6 against Salmonella spp.: Phage Application in Milk. Biologics 2021, 1, 164-176. https://doi.org/10.3390/ biologics1020010

Academic Editor: Mark Chambers

Received: 15 June 2021

Accepted: 27 July 2021

Published: 2 August 2021

Publisher's Note: MDPI stays neutral with regard to jurisdictional claims in published maps and institutional affiliations.

Copyright: (c) 2021 by the authors. Licensee MDPI, Basel, Switzerland. This article is an open access article distributed under the terms and conditions of the Creative Commons Attribution (CC BY) license (https:/ / creativecommons.org/licenses/by/ $4.0 /)$.

\begin{abstract}
Food safety is very important in the food industry as most pathogenic bacteria can cause food-borne diseases and negatively affect public health. In the milk industry, contamination with Salmonella has always been a challenge, but the risks have dramatically increased as almost all bacteria now show resistance to a wide range of commercial antibiotics. This study aimed to isolate a bacteriophage to be used as a bactericidal agent against Salmonella in milk and dairy products. Here, phage ZCSE6 has been isolated from raw milk sample sand molecularly and chemically characterized. At different multiplicities of infection (MOIs) of 0.1, 0.01, and 0.001, the phageSalmonella interaction was studied for $6 \mathrm{~h}$ at $37^{\circ} \mathrm{C}$ and $24 \mathrm{~h}$ at $8^{\circ} \mathrm{C}$. In addition, ZCSE6 was tested against Salmonella contamination in milk to examine its lytic activity for $3 \mathrm{~h}$ at $37^{\circ} \mathrm{C}$. The results showed that ZCSE6 has a small genome size $(<48.5 \mathrm{kbp})$ and belongs to the Siphovirus family. Phage ZCSE6 revealed a high thermal and $\mathrm{pH}$ stability at various conditions that mimic milk manufacturing and supply chain conditions. It also demonstrated a significant reduction in Salmonella concentration in media at various MOIs, with higher bacterial eradication at higher MOI. Moreover, it significantly reduced Salmonella growth (MOI 1) in milk, manifesting a 1000-fold decrease in bacteria concentration following $3 \mathrm{~h}$ incubation at $37^{\circ} \mathrm{C}$. The results highlighted the strong ability of ZCSE6 to kill Salmonella and control its growth in milk. Thus, ZCSE6 is recommended as a biocontrol agent in milk to limit bacterial growth and increase the milk shelf-life.
\end{abstract}

Keywords: phage therapy; applied microbiology; milk industry; foodborne bacteria; antibiotic resistance; virulent

\section{Introduction}

Milk and its byproducts are a crucial source of nutrition due to their high contents of protein and minerals. However, milk is prone to microbial contamination by both pathogenic and spoilage organisms. This will lead to economic and public health challenges due to food spoilage, infectious diseases such as Shiga toxin-producing Escherichia coli (STEC), enterotoxin-producing Staphylococcus aureus, Salmonella, and Listeria monocytogenes, and the high cost of disease treatment, especially in low-income communities [1,2]. In the dairy industry, milk quality and safety have always been a priority, through various milk disinfection approaches to eliminate and control bacterial growth [3].

One of the widely disseminated bacteria within the milk food process is Salmonella, a facultative anaerobic Gram-negative bacterium, that belongs to the Enterobacteriaceae family. Salmonella usually spreads via the consumption of contaminated food such as milk, egg, and poultry meat. Salmonella enterica serovar Enteritidis is mostly isolated from 
salmonellosis epidemics caused by the ingestion of poultry products [4]. Recent reports highlighted the spread of antibiotic-resistant $S$. enterica in chicken and poultry farms in Egypt $[5,6]$. Improper handling in animal-derived foods would likely be a significant contributor to disease onset [7,8], but in plant-derived foods, cross-contamination via fecal residues has also a problematic role $[9,10]$. Moreover, $S$. Enteritidis is considered the main serotype that is associated with human infection, and about $87 \%$ of Salmonella outbreaks are due to house-made food that is contaminated with Salmonella. Thus, it is estimated that most of Salmonella foodborne disease is triggered by inappropriate handling [11].

The rise of antibiotic-resistant strains of $S$. Enteritidis encourages scientists to find new approaches to control the spread of this bacterium along the food chain [12]. Among the effective approaches are the rational running of the process line, good production hygiene, and the well-designed use of biocides and disinfectants. Although adequate cleaning processes are taken into consideration, bacteria can still be found on food and surfaces [13]. A potential biocontrol agent in food is the usage of bacteriophages which are bacterial viruses that have several advantages over antibiotics such as the inability to infect human cells, specificity towards bacteria, and a ubiquitous presence in nature that allows them to be used in food safety interventions $[14,15]$. Nevertheless, phage has some disadvantages, such as the emergence of resistant bacteria, phage-mediated transfer of antibiotic-resistance genes, lysogenic conversion, and other destabilizing factors such as $\mathrm{pH}$, temperature, and food compounds which can affect phage activity [16]. Consequently, the selection and characterization of bacteriophages are essential steps to confirm their effectiveness for biocontrol use [17].

Many studies have demonstrated that bacteriophage can be used safely to reduce $S$. Enteritidis in milk and milk products. Numerous Salmonella phages were designated as biocontrol agents against $S$. Enteritidis in poultry [12,18-22]. Previous studies emphasized that bacteriophage was able to control salmonellosis much more effectively than the antibiotics only and, in some cases, it is better than a combination of both bacteriophage and antibiotics [23,24]. Previous works have highlighted the importance of bacteriophage in preventing food poisoning with $S$. Enteritidis $[3,25]$ and confirmed that bacteriophage was able to inhibit the growth of $S$. Typhimurium in milk while maintaining milk color and stability as it is stored at $4{ }^{\circ} \mathrm{C}[10,26]$.

To date, various phage therapy applications have been reported with an effort to optimize the dosage forms and mimic the real milk production line. Thus, the aim of this study is to isolate and characterize phage from milk samples to control and reduce the presence of Salmonella spp. in milk while maintaining milk stability.

\section{Results}

\subsection{Phage Specificity, Lytic Profile, and Efficiency of Plating}

Phage ZCSE6 isolated from raw milk had a potent antibacterial effect against many of the isolates; showing an ability to form lysis zones ( $\geq 20$ plaques) on 14 out of 39 Salmonella spp. isolates and one out of six E. coli isolates. It did not display any lytic activity against five Klebsiella pneumoniae strains or five Pseudomonas aeruginosa strains. The efficiency of plating (EOP) and lytic profile for phage ZCSE6 were further investigated against nine Salmonella strains that were randomly selected from the 14 susceptible strains identified by the initial screen. Four of these Salmonella isolates showed an EOP of more than 1, and three of them were between 1 and 0.5 , while the other two strains were lower than 0.5 (Table 1). Plaque morphology can be described as halo or turbid: Halo plaques are a clear spot surrounded by a large halo, whereas the turbid plaques represent an unclear spot. The plaques formed by phage ZCSE6 had various morphologies on the different strains, with a cloudy zone observed around the center in seven out of nine strains (Figure 1A). The serotypes of selected samples indicated that CMPZCSB1 and CMPZCSB5 are Salmonella Typhimurium, CMPZCSB2 and CMPZCSB4 are Salmonella Blegdam, CMPZCSB3 is Salmonella Kentucky, CMPZCSB6 is Salmonella Gallinarum, and CMPZCSB7 and CMPZCSB9 are Salmonella Enteritidis (Table 1). Thus, we suggest that phage ZCSE6 has a bacteriolytic activity against 
a wide range of different Salmonella serotypes. However, further studies are needed to investigate the change of EOP for the selected phage on a bigger bacterial library including different serotypes of Salmonella.

Table 1. Shows the plaque morphology and EOP of ZCSE6 against various Salmonella isolates.

\begin{tabular}{|c|c|c|c|c|}
\hline ID & Salmonella Bacteria & Serotype & EOP & Plaque Morphology \\
\hline CMPZCSB1 & Salmonella enterica & enterica serotype Typhimurium & $\geq 1$ & plaques with a halo \\
\hline CMPZCSB2 & Salmonella enterica & enterica serotype Blegdam & $<0.5$ & plaques with a halo \\
\hline CMPZCSB3 & Salmonella enterica & enterica serotype Kentucky & $\geq 1$ & turbid plaque \\
\hline CMPZCSB4 & Salmonella enterica & enterica serotype Blegdam & $<1 \geq 0.5$ & plaques with a halo \\
\hline CMPZCSB5 & Salmonella enterica & enterica serotype Typhimurium & $\geq 1$ & turbid plaque \\
\hline CMPZCSB6 & Salmonella enterica & enterica serotype Gallinarum & $<1 \geq 0.5$ & plaques with a halo \\
\hline CMPZCSB7 & Salmonella enterica & enterica serotype Enteritidis & $<\overline{0.5}$ & plaques with a halo \\
\hline CMPZCSB8 & Salmonella enterica & Salmonella enterica spp. & $<1 \geq 0.5$ & plaques with a halo \\
\hline CMPZCSB9 & Salmonella enterica & enterica serotype Enteritidis & $\geq 1$ & plaques with a halo \\
\hline
\end{tabular}

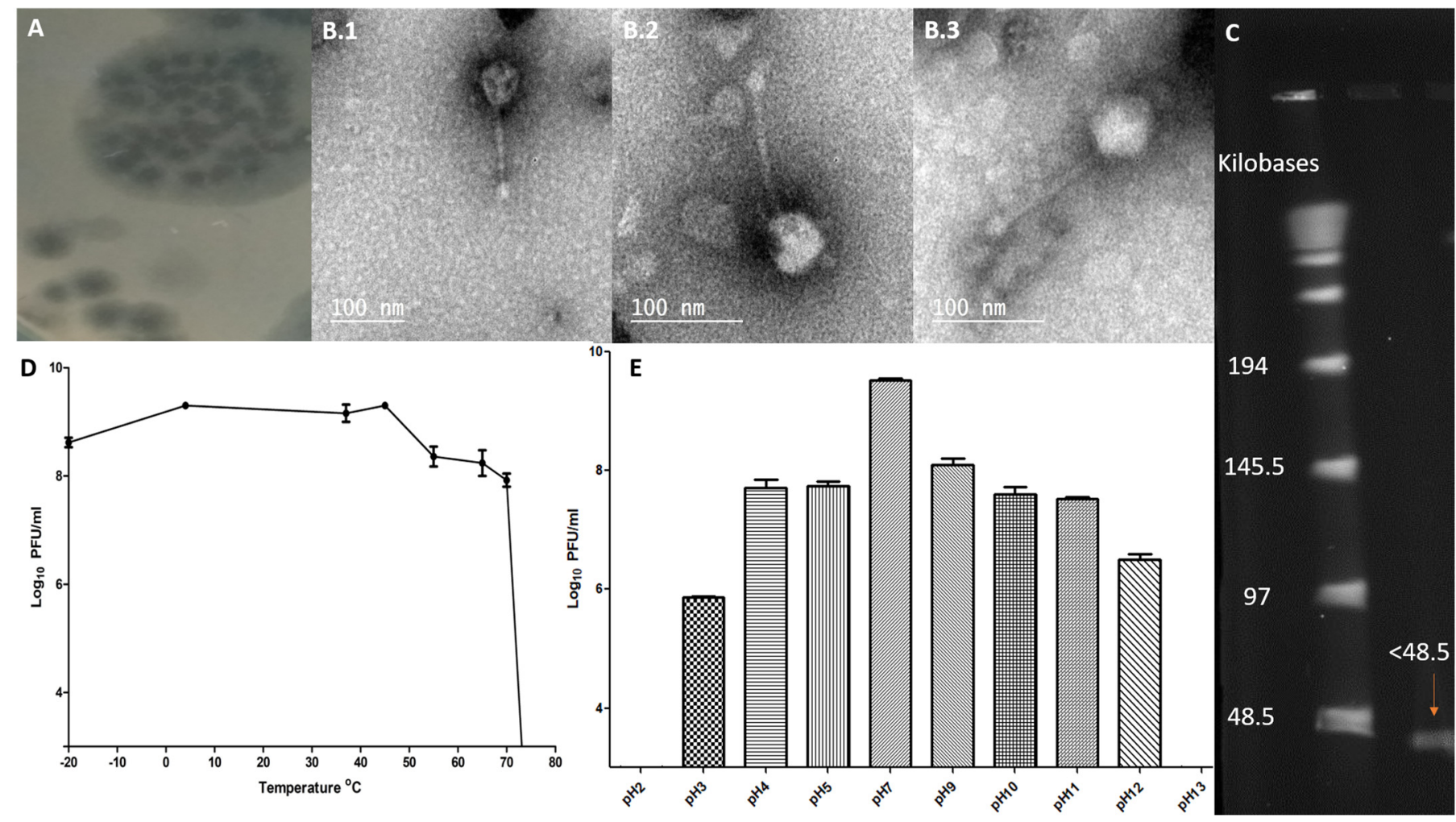

Figure 1. represents phage characterization. (A) The morphology of plaques on a plate containing bacterial overlay; (B.1-B.3) Different images for the same phage illustrating its morphology with scale bar of $100 \mathrm{~nm}$; and (C) The pulsed-field gel electrophoreses (PFGE) for phage ZCSE6, where the orange arrow indicates the position of the genome band on the agarose. The color contrast was enhanced by using Snapseed v2.20.2. (D) Phage stability against temperatures. (E) The sensitivity of phage ZCSE6 against the various $\mathrm{pH}$ levels.

\subsection{Morphological Characteristics of ZCSE6 and Genome Size}

The morphology of phage ZCSE6 belongs to the family of Siphoviridae (Figure 1(B.1-B.3)), with an icosahedral head and a long tail with high density at the end representing a short tail-spikes complex. The phage head size is $52.2 \pm 3.9 \mathrm{~nm}$, and the tail length is $111.6 \pm 5.5 \mathrm{~nm}$. The genome size for phage ZCSE6 is less than 48 kilobases (Figure 1C). 


\subsection{Phage Stability against Temperature and $\mathrm{pH}$ Levels}

The ability of isolated phages to withstand a wide range of temperature and $\mathrm{pH}$ is a critical factor that may affect the applicability of phages as a biocontrol agent. The stability of phage ZCSE6 at various temperatures and $\mathrm{pH}$ levels was measured. Compared to the starting phage titer, the phage was stable at approximately $2 \times 10^{9}$ plaque-forming unit (PFU) $/ \mathrm{mL}$ after $1 \mathrm{~h}$ of incubation at $45^{\circ} \mathrm{C}$. However, the phage titer at $65^{\circ} \mathrm{C}$ and $-20^{\circ} \mathrm{C}$ was reduced 10 -fold and continued to decrease at $70^{\circ} \mathrm{C}$ to below $10^{8} \mathrm{PFU} / \mathrm{mL}$ after $1 \mathrm{~h}$ of incubation. Phage recovery at a higher temperature, above $75^{\circ} \mathrm{C}$, was below the limit of detection $\left(<10^{3} \mathrm{PFU} / \mathrm{mL}\right.$ ) (Figure 1D). Phage was treated at different $\mathrm{pH}$ values to study the $\mathrm{pH}$ stability. The optimal $\mathrm{pH}$ for phage ZCSE6 was 7, and there was a reduction in phage titers in both an acidic and basic environment. The phage titers in $\mathrm{pH}$ levels 3,4 , $5,7,9,10,11$, and 12 were $5.86 \pm 0.03,7.71 \pm 0.23,7.73 \pm 0.15,9.51 \pm 0.07,8.1 \pm 0.17$, $7.59 \pm 0.21,7.51 \pm 0.07$, and $6.5 \pm 0.17 \log _{10} \mathrm{PFU} / \mathrm{mL}$, respectively (Figure $1 \mathrm{E}$ ). Upon exposure to $\mathrm{pH} 2$ and $\mathrm{pH} 13$, the phage titer dropped below the detection limit.

\subsection{The One-Step Growth Curve}

To demonstrate the lysis ability of phage ZCSE6 against Salmonella bacteria, aerobic single-step growth experiments were carried out at an MOI of 1 . The latent period (the time from phage adsorption to the release) and burst size (the number of released virions per single bacterium) were determined using the one-step-growth curve analysis (Figure 2A). The curve displayed that the latent period was around $20 \mathrm{~min}$, and a rise time of $25 \mathrm{~min}$, while the burst size was around 106 phages per single host bacterium.
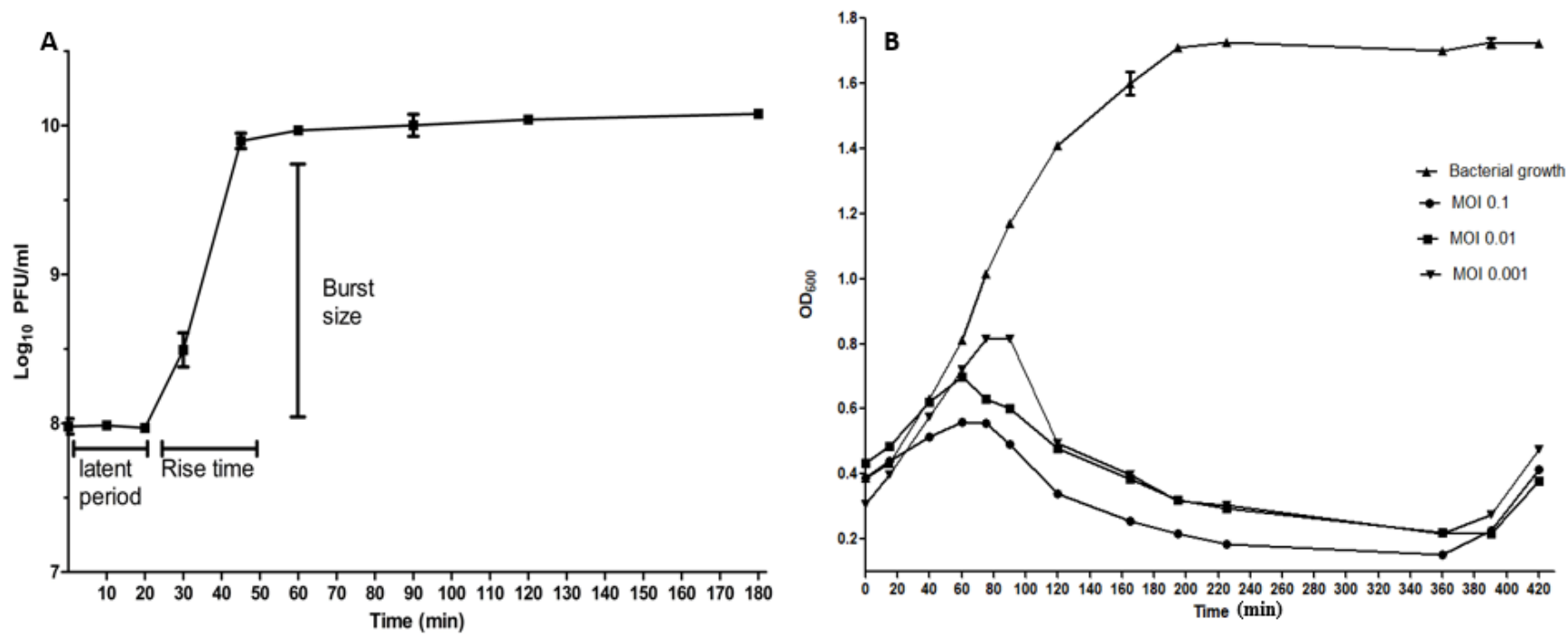

Figure 2. displays the behavior of phage ZCSE6 lysis against bacterial host. (A) One-step growth curve MOI of 1 and (B) time-killing curve with different MOIs.

\subsection{Time-Killing Curve}

The bacteriolytic effect of phage ZCSE6 on Salmonella strain was investigated in vitro at different MOIs $(0.1,0.01$, and 0.001$)$ (Figure $2 \mathrm{~B})$. The absorbance $\left(\mathrm{OD}_{600}\right)$ of the bacteria without treatment with phage (control) increased rapidly from $\mathrm{OD}_{600}=0.387 \pm 0.006$ to $\mathrm{OD}_{600}=1.722 \pm 0.013$ after $420 \mathrm{~min}$. All MOIs of phage ZCSE6 infected cultures showed significant bacterial killing activity $(p<0.001)$ during the first $360 \mathrm{~min}(6 \mathrm{~h})$ of the infection period. For an MOI of 0.1 , biocontrol activity was observed within the first 20 to $40 \mathrm{~min}$ of infection, and lytic activity was confirmed based on the change in the bacterial $\mathrm{OD}_{600}$ that decreased from $0.386 \pm 0.022$ to $0.151 \pm 0.003$ within the first $360 \mathrm{~min}$ of incubation. Correspondingly, bacteria infected with phage ZCSE6 at a reduced MOI of 0.01 took longer to exhibit inhibition activity ( $60 \mathrm{~min})$ with a reduction in 
bacterial turbidity, from $\mathrm{OD}_{600}=0.434 \pm 0.004$ to $0.216 \pm 0.003$, observed after $390 \mathrm{~min}$ of infection. Bacteria incubated with phage ZCSE6 at an MOI of 0.001 needed up to $100 \mathrm{~min}$ to cause a bacteriostatic activity, and $360 \mathrm{~min}$ to reduce the bacterial absorbance from $\mathrm{OD}_{600}=0.308 \pm 0.009$ to $0.218 \pm 0.023$. A secondary bacterial growth was detected in all cultures containing phage after $360 \mathrm{~min}$ of infection.

\subsection{Lytic Activity at Low Temperature}

To test the lysis efficiency of phage ZCSE6 at low temperatures to mimic the conditions of the chilled food chain and milk preservation, an infection experiment was performed at $8{ }^{\circ} \mathrm{C}$ for $24 \mathrm{~h}$. After 4 hours, there was no significant difference between the control $\left(3.66 \times 10^{6} \pm 1.3 \times 10^{6} \mathrm{CFU} / \mathrm{mL}\right)$ and bacteria treated with phage $\left(5 \times 10^{6} \pm\right.$ $\left.1.1 \times 10^{6} \mathrm{CFU} / \mathrm{mL}\right)(p>0.05)$. However, after $24 \mathrm{~h}$, there was a significant difference between control $1.5 \times 10^{7} \pm 4.2 \times 10^{6} \mathrm{CFU} / \mathrm{mL}$ and the one treated with phage $1.67 \times 10^{3}$ $\pm 1.33 \times 10^{3} \mathrm{CFU} / \mathrm{mL}$ with a $4 \log _{10}$ reduction in bacterial titer $(p<0.005)$ (Figure $\left.3 \mathrm{~A}\right)$.
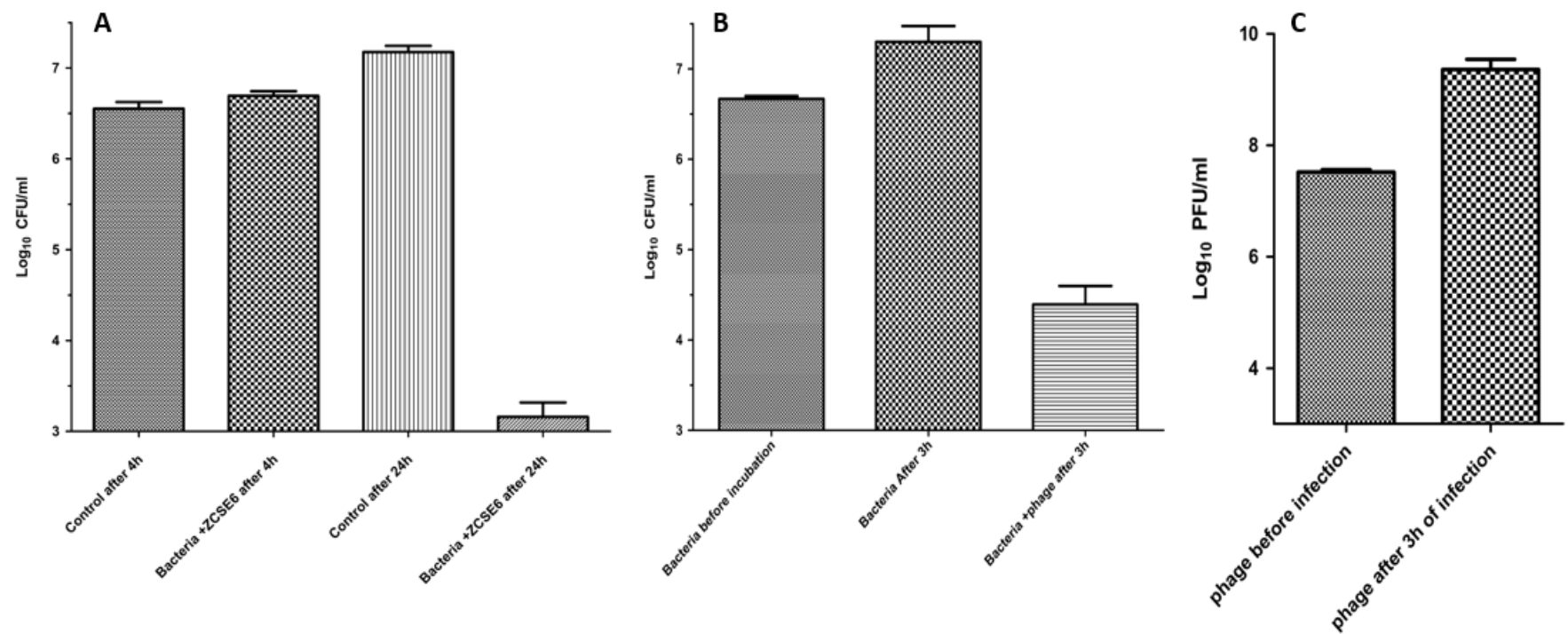

Figure 3. illustrates (A) the bacterial survival at low-temperature $8{ }^{\circ} \mathrm{C}$ in media after 4 and $24 \mathrm{~h}$; (B) Bacterial reduction in milk at $37^{\circ} \mathrm{C}$ after $3 \mathrm{~h}$ of phage treatment; and (C) the phage propagation in milk containing Salmonella bacteria after $3 \mathrm{~h}$ of incubation at $37^{\circ} \mathrm{C}$.

\subsection{Suppression of Salmonella in Milk by Using Phage ZCSE6}

To investigate whether the phage reduces Salmonella growth in milk under low temperature $\left(37^{\circ} \mathrm{C}\right)$ or not, we investigated the reduction by enumerating the viable cell numbers by adding phage ZCSE6 into whole milk (Figure 3B). Without phage treatment (control), Salmonella cell numbers reached $2.3 \times 10^{7} \pm 1.7 \times 10^{7} \mathrm{CFU} / \mathrm{mL}$ in whole milk after $3 \mathrm{~h}$ of incubation. In contrast, in the treated sample, the Salmonella cell number was only $3 \times 10^{4} \pm 2.2 \times 10^{4} \mathrm{CFU} / \mathrm{mL}(p<0.05)$, which indicated that the treated bacterial cells decreased by 1000 -fold compared to those without treatment. In addition, the phage titers increased significantly from $3.3 \times 10^{7} \pm 6.5 \times 10^{6} \mathrm{PFU} / \mathrm{mL}$ to $2.6 \times 10^{9} \pm 1.7 \times 10^{9} \mathrm{PFU} / \mathrm{mL}$ at $37^{\circ} \mathrm{C}(p<0.05)$ (Figure $\left.3 \mathrm{C}\right)$.

Another experiment was conducted to predict the ability of phage ZCSE6 to reduce the bacteria present in milk over $24 \mathrm{~h}$ at room temperature $\left(25^{\circ} \mathrm{C}\right)$. The phage successfully reduced the bacterial count from $2 \times 10^{7} \mathrm{CFU} / \mathrm{mL}$ to $2 \times 10^{3} \mathrm{CFU} / \mathrm{mL}$ in the treated group in comparison to the control sample (Figure $4 \mathrm{~A}$ ), however secondary bacterial growth due to phage resistance is increased. The efficiency of phage to control the bacterial growth in milk stored at the optimal temperature to store the milk $\left(4^{\circ} \mathrm{C}\right)$, was better than that the efficiency of phage to control the bacterial growth at room temperature $\left(25^{\circ} \mathrm{C}\right)$ due to the absence of the secondary bacterial growth after $24 \mathrm{~h}$ (Figure $4 \mathrm{~B}$ ). In addition, the phage 
showed significant stability if the milk was stored at $4{ }^{\circ} \mathrm{C}$ for 6 days without any reduction in phage titer (Figure $4 \mathrm{C}$ ).

A

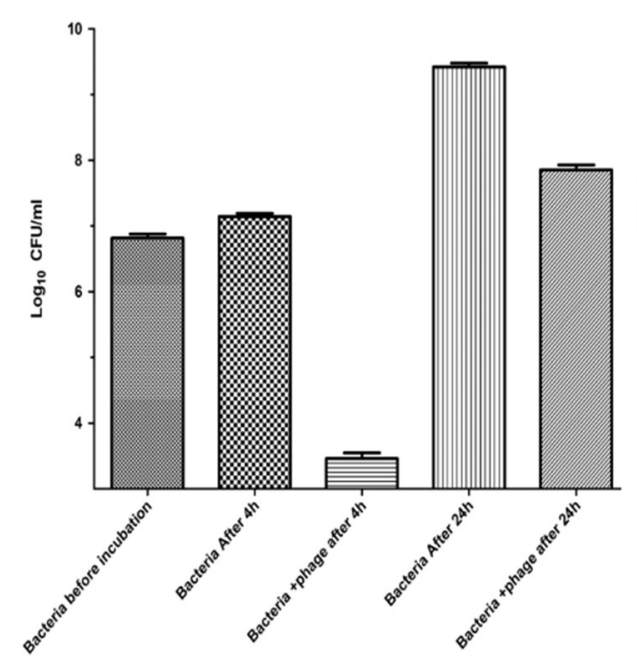

B

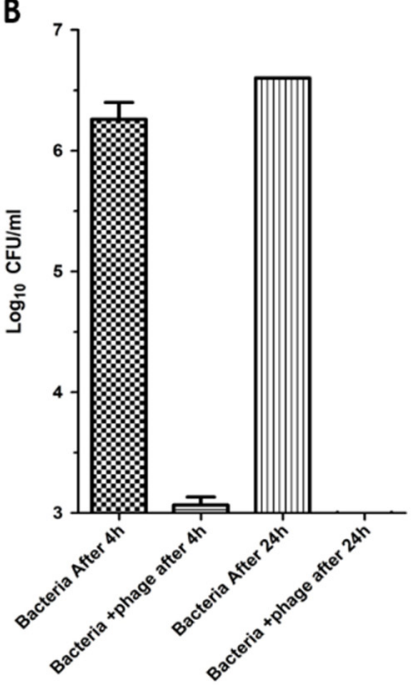

C

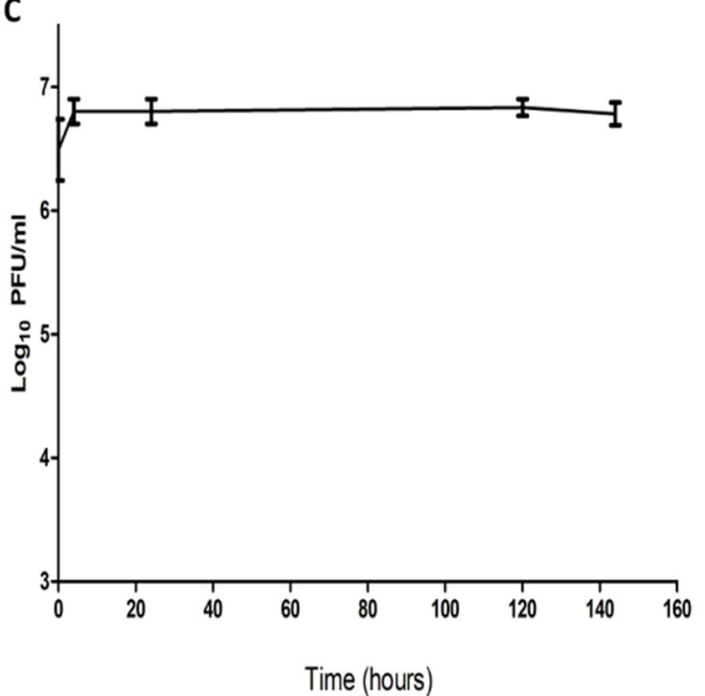

Figure 4. Illustrates (A) the bacterial survivors in treated milk stored at $25^{\circ} \mathrm{C}$ after 4 and $24 \mathrm{~h}$; (B) bacterial survivors in treated milk stored at $4{ }^{\circ} \mathrm{C}$ after 4 and $24 \mathrm{~h}$; and (C) the phage stability in Salmonella milk-free over 6 days of incubation at $4{ }^{\circ} \mathrm{C}$.

\section{Discussion}

Salmonella is one of the most pathogenic bacteria in contaminated food, and it infects the digestive system. Food can be contaminated with these bacteria through crosscontamination due to bad handling. The implementation of antibiotics to control bacterial infections is significantly reduced these days due to the increasing incidences of antibiotic resistance among bacterial isolates; accordingly, the rate of related morbidity and mortality has increased worldwide. The antibiotic resistance crisis occurred due to the misuse and abuse of antibiotics by both human and industrial sectors [27]. Therefore, bacteriophages are introduced as alternatives to antibiotics [28]. In order to increase the benefits of phage-based therapies, a phage data bank is essential to build a foundation to understand phage-bacteria interactions and the possible risks and benefits of phage applications, especially in medical fields [29]. Thus, a significant effort was conducted to isolate and characterize novel phages against a wide range of bacteria to be used in the future in personalized medicine. Moreover, the delivery methods of lytic phages are a critical concern to maximize the benefits, limit any undesired consequences, and build an industrial model of phage application, storage, and delivery. In this study, we successfully isolated phage ZCSE6 from milk samples, characterized it, and studied the phage-bacteria dynamics to provide a good model to control the growth of pathogenic Salmonella in general, and particularly in milk.

Phage ZCSE6 was found to be effective against many strains of the tested Salmonella when it presented clear plaques against 14 Salmonella isolates without lytic activity against K. pneumoniae or P. aeruginosa isolates, which indicates the high specificity of isolated phage against Salmonella. On the other hand, the ability of phage ZCSE6 to lyse E. coli indicates that the phage can infect two different bacterial genus. Thus, phage ZCSE6 is a "divalent phage", as it has been reported before for Salmonella and E. coli phages [30,31]. Moreover, the host range of phage ZCSE6 solves one of the huge issues of antibiotics, as the narrow host range of bacteriophage reduces the risk of affecting normal microbiota and developing resistance among bacteria. However, it might provide a disadvantage, as many of the infections may include more than one bacterial strain [32]. The plaques showed various morphologies on the different strains, as described above; phage ZCSE6 showed a cloudy 
zone around the center in seven strains (Figure 1A) as described in another study [33], and two strains did not display those patterns (Table 1).

Regarding the sensitivity of phage ZCSE6 toward temperature, there was a reduction in phage titer after incubating the phage at $-20{ }^{\circ} \mathrm{C}$ due to the formation of ice crystals, thus the glycerol is preferred to be added to keep the phages safe at temperatures lower than $0{ }^{\circ} \mathrm{C}$ [34]. Furthermore, the thermal stability of phage ZCSE6 to a wide range of temperatures ranging from $-20^{\circ} \mathrm{C}$ to $70{ }^{\circ} \mathrm{C}$ was confirmed. Thus, it is recommended to apply phage in milk treatment, as a preservative against bacterial infection, following the regular thermal treatment to avoid post-intervention contamination [35]. According to the data of phage stability in different $\mathrm{pH}$ environments, phage ZCSE6 was found to be sensitive towards the change in $\mathrm{pH}$, yet it tolerated the extreme basic $\mathrm{pH}$ values, up to $\mathrm{pH}$ of 12 , with a reduction of $3 \log _{10} \mathrm{PFU} / \mathrm{mL}(p<0.005)$ compared to $\mathrm{pH} 7$. However, it cannot tolerate the extreme acidic $\mathrm{pH}$ values, such as $\mathrm{pH}$ of 2 , which is the same acidity of the stomach. This makes the phage inactive when orally administrated, similar to most of the previously reported phages ( $\geq 12$ and $\leq 2)[36,37]$. To overcome this disadvantage, many approaches are taking place, such as loading the phage in more stable coats, as reported in [37]. On the other hand, other methods might be useful for the delivery of phage, such as; the delivery of phage in a solid formula, such as suppository through anal [38]. More studies are needed to develop more effective and friendly delivery systems and to increase phage stability in harsh body environments.

The burst size is an important criterion that should be estimated to understand the replication dynamics of the isolated phage [39]. It was reported that burst sizes are variable in Siphovirus (between 60 and $147 \mathrm{PFU} / \mathrm{mL}$ ), whereas latent periods and rise times range from 16 to $55 \mathrm{~min}$ and 24 to $65 \mathrm{~min}$, respectively [40,41]. Phages have different activities against bacteria, including (i) bacteriostatic activity that stops the bacterial growth, as in Acinetobacter baumannii after $360 \mathrm{~min}$ of incubation with phages [42,43], and P. aeruginosa [44]; and (ii) bacteriolytic activity, represented by the reduction in bacterial $\mathrm{OD}_{600}$ from starting concentration, as in A. baumannii [45] and Aeromonas hydrophila [46]. In this study, phage ZCSE6 presented a bactericidal effect against Salmonella with a significant reduction rate compared to the control. Following the common intuition, the higher dose of ZCSE6 (MOI 0.1) provided a faster lytic effect than the lower phage titer (MOI 0.01 and 0.001).

Salmonella survives in milk at storage temperatures below $10^{\circ} \mathrm{C}$ with a slow growth rate [26]. The application of phage as an effective control agent against bacteria in milk was reported in recent studies, including the suppression of P. lactis [47], S. Typhimurium [26], and E. coli O157: H7 [48]. In this study, in the absence of phage, levels of Salmonella increased gradually after $24 \mathrm{~h}$ of incubation, and the bacteria treated with phage decreased slowly without secondary bacterial growth. Moreover, the phage titer increased after $3 \mathrm{~h}$ of incubation with the bacteria in milk, indicating the ability of the phage to attach and lyse the bacterial cells in a thick, protein and mineral-rich medium. This bacteriolytic ability of the phage in the milk was confirmed by the reduction in the viable bacterial cells after $3 \mathrm{~h}$ of incubation. These data support the use of bacteriophage as an alternative antibiotic-free method to control bacterial contamination in milk.

The dynamic process of isolating novel phages with complete characterization from isolation to application enriches our knowledge about the phage world. In addition, it provides information about its evolution and helps to determine the most suitable application according to its characteristics [31,49]. Nowadays, several phages that target Salmonella in foodstuff are found in the market, including PhageGuard STM that reduces the bacteria in beef meat [50]. Other products found in the market include: SalmoLyse ${ }^{\circledR}$ that can be used as a phage spray in chicken, tuna, turkey, and plants such as cantaloupe and lettuce [51], and SalmoFresh ${ }^{\mathrm{TM}}$ that can be used in packaging and reduce Salmonella contamination in chicken breast $[52,53]$. Here, we discussed the possibility of using a novel phage to reduce Salmonella bacteria in milk. The phage ZCSE6 can be used in the future as a preservative agent against contamination due to its stability in milk at $4{ }^{\circ} \mathrm{C}$ (Figure 4C). However, the phage cannot remove the endotoxins that are produced 
from bacterial lysis in vivo, and the use of phage in the food market was approved by FDA as a decontaminator, sanitizer, and diagnostic agent [54]. The reason behind our recommendations to use phage ZCSE6 to reduce food poisoning is due to its ability to kill the bacteria with high bacteriolytic activity for several days. Based on that, there is a need for several studies to confirm the possibility of different phages to be effectively used in commercial food manufacture. That will include improving the thermal stability of phages for tolerating the high temperatures in food thermal processing applications.

\section{Materials and Methods}

\subsection{Bacterial Characterization and Growth Media}

Herein, the study was conducted using the multidrug-resistant (MDR) Salmonella bacterium as the main host CMPZCSB1. The strain is a gift, from Professor Ian Connerton (the University of Nottingham, Nottingham, UK) and was confirmed by using selective enrichment media Rappaport-Vassiliadis soya peptone broth (RVS broth, Oxoid, Hampshire, UK), selective media Xylose Lysine Deoxycholate agar (XLD agar, Bio Lab, Budapest, Hungary), and biochemical assays including citrate, catalase, urease, and indole test. The confirmed stocks were kept in $20 \%(v / v)$ glycerol at $-80^{\circ} \mathrm{C}$ until needed. Salmonella was grown on Tryptic Soy Agar (TSA; Oxoid, UK) or Tryptic Soya broth (TSB; Oxoid, UK) at $37^{\circ} \mathrm{C}$ in aerobic conditions to perform different experiments.

\subsection{Isolation, Amplification, and Purification of Phage ZCSE6 from Milk}

Five milliliters of raw milk collected from different cow farms in Giza, Egypt were mixed with $5 \mathrm{~mL}$ of TSB containing Salmonella as a bacterial host strain. After incubation overnight at $37^{\circ} \mathrm{C}$, the sample was centrifuged for $15 \mathrm{~min}$ at $6400 \times g$ at $4{ }^{\circ} \mathrm{C}$. The doubleagar overlay plaque assays were used to quantify the titer and isolate a single plaque by sterile micropipette tip to obtain a single phage $[55,56]$. This step was performed at least 3 times to make sure that we isolated a single plaque for the amplification purpose. In the amplification process, the phage ZCSE6 was added to Salmonella at $\mathrm{OD}_{600} 0.2-0.6$ with MOI from 0.1 to 1 and left for around $4 \mathrm{~h}$ (or until the color of TSB media changes from turbid to clear). The chloroform was added for $30 \mathrm{~min}$ before centrifuging the lysates for another $15 \mathrm{~min}$ at $6400 \times \mathrm{g}$ at $4{ }^{\circ} \mathrm{C}$. The supernatant containing phages was then centrifuged at $15,300 \times \mathrm{g}$ for $1 \mathrm{~h}$ at $4{ }^{\circ} \mathrm{C}$. Phage pellets were resuspended in SM buffer $(100 \mathrm{mM}$ $\mathrm{MgSO}_{4} / 7 \mathrm{H}_{2} \mathrm{O} ; 10 \mathrm{mM} \mathrm{NaCl} ; 50 \mathrm{mM}$ Tris- $\mathrm{HCl}$; $\mathrm{pH}$ 7.5) before filtration with $0.22 \mu \mathrm{m}$ syringe filters (Chrom Tech, Apple Valley, MN, USA). The phage titer was determined using standard double-agar overlay plaque assays [28] and stored in the fridge at $4{ }^{\circ} \mathrm{C}$ for further use.

\subsection{Host Range, Lytic Profile, and EOP of Phage ZCSE6}

The host range of phage ZCSE6 was measured using an in-house panel of 39 Salmonella isolates (Supplementary Data: Table S1), 6 E. coli, 5 K. pneumoniae, and 5 P. aeruginosa strains. Then, the lytic profile and EOP of the phage were determined using a panel of positive host Salmonella strains. Criteria for phage selection involved identifying phages displaying lysis against the bacterial panel, alongside the ability to produce clear plaques on the host bacterium. The phage titer applied to lawns was not less than $10^{9}$ plaque-forming units $(\mathrm{PFU}) / \mathrm{mL}$, and the phage was 10-fold serially diluted and measured in triplicate against 8 random, susceptible, and isolated bacteria using double-agar overlay plaque assays. EOP was then calculated as the average PFU on each bacterium divided by the average PFU on all host bacteria.

\subsection{Pulsed-Field Gel Electrophoresis (PFGE)}

Phage plugs were prepared, as described previously [57], by suspending $200 \mu \mathrm{L}$ of phage in $200 \mu \mathrm{L}$ agarose gel prepared from $1 \times$ TE buffer (Tris-HCl, Loba Chemie, Mumbai, India, EDTA, Fisher chemical, Pittsburgh, PA, USA, pH 8) and 1.4\% agarose (Lonza, Basel, Switzerland), and left to dry for around $15 \mathrm{~min}$. Then, $5 \mathrm{~mL}$ of lysis buffer (proteinase $\mathrm{K}$, 
Fisher scientific, USA, Tris-HCl, EDTA, pH 8) was added to the plugs and incubated for $18 \mathrm{~h}$ at $55^{\circ} \mathrm{C}$ for digestion. Following the incubation period, plugs were transferred to $5 \mathrm{~mL}$ washing buffer and incubated for $1 \mathrm{~h}$ at $37^{\circ} \mathrm{C}$ and another two washing steps were performed for $20 \mathrm{~min}$ in $1 \mathrm{~mL}$ washing buffer. Then, $1 \%$ agarose gel was prepared using $0.5 \times$ TBE buffer (Tris-HCl, boric acid, Fisher chemical, USA, EDTA, pH 8) and $2700 \mathrm{~mL}$ of $0.5 \mathrm{TBE}$ buffer was prepared for the run. The plugs were then inserted into the gel, and the gel was run for $18 \mathrm{~h}$ at $6 \mathrm{~V}$, with a switch time of $5 \mathrm{~s}$ initial and $13 \mathrm{~s}$ final, and the cooling module was set at $14{ }^{\circ} \mathrm{C}$. The size of the genome was determined by comparison to standard concatenated lambda DNA markers (Sigma Aldrich, Gillingham, UK). After incubation, the gel was visualized using Ethidium bromide and imaged using BioRad Chemidoc.

\subsection{Morphology Investigation by Transmission Electron Microscopy (TEM)}

The morphology of the phage was imaged as described before by using TEM at the National Research Center (Cairo, Egypt) [58]. Ten $\mu$ L of phage ZCSE6 $\left(10^{9} \mathrm{PFU} / \mathrm{mL}\right)$ were placed on a grid fixed with adding $2.5 \%$ glutaraldehyde and stained with $3 \%$ phosphotungstic acid. The stained phage was observed using a high resolution-transmission electron microscope (HR-TEM) (JEM-2100, JEOL, Tokyo, Japan) and images were captured at different magnifications.

\subsection{The Effect of $\mathrm{pH}$ and Temperature on Phage Stability}

The impact of different $\mathrm{pH}$ and temperatures on the lytic activity of phage was studied. To investigate the $\mathrm{pH}$ effect, $100 \mu \mathrm{L}$ of ZCSE6 $\left(10^{9} \mathrm{PFU} / \mathrm{mL}\right)$ was added to $9.9 \mathrm{~mL}$ of sterile water at different $\mathrm{pH}$ levels (ranging from 2 to 13) using SM phage buffer $(5.8 \mathrm{~g}$ of NaCl, $1.2 \mathrm{~g}$ of $\mathrm{MgSO}_{4}$, and $50 \mathrm{~mL}$ of $1 \mathrm{M}$ Tris- $\mathrm{HCl} \mathrm{pH} 7.5$ with $0.1 \mathrm{~g}$ of gelatin in $1000 \mathrm{~mL}$ of deionized water) and adjusted by using $\mathrm{NaOH}$ or $\mathrm{HCl}$ and incubated at $4{ }^{\circ} \mathrm{C}$ for $24 \mathrm{~h}$. To investigate the temperature effect, $100 \mu \mathrm{L}$ of ZCSE6 $\left(10^{9} \mathrm{PFU} / \mathrm{mL}\right)$ was added to $900 \mu \mathrm{L}$ of TSB buffer ( $\mathrm{pH} 7)$ and incubated at different temperatures $\left(-20^{\circ} \mathrm{C}, 4^{\circ} \mathrm{C}, 37^{\circ} \mathrm{C}, 45^{\circ} \mathrm{C}\right.$, $55^{\circ} \mathrm{C}, 65^{\circ} \mathrm{C}, 70^{\circ} \mathrm{C}, 75^{\circ} \mathrm{C}, 80^{\circ} \mathrm{C}$, and $90^{\circ} \mathrm{C}$ ) for $1 \mathrm{~h}$. Finally, a plaque assay technique was conducted to detect the reduction in phage titer and testify to phage stability.

\subsection{One-Step Growth Curve of ZCSE6}

For this experiment, bacterial culture was prepared with $\mathrm{CFU} \sim 10^{8} \mathrm{CFU} / \mathrm{mL}$ and infected with phage at MOI of 1 (PFU $\sim 10^{8} \mathrm{PFU} / \mathrm{mL}$ ). The multiplicity of infection (MOI) was calculated using the following equation:

$$
\text { MOI }=\frac{\text { PFU } \times \text { The volume of ZCSE6 }(\mathrm{mL})}{\mathrm{CFU} \times \text { The volume of bacterial culture }(\mathrm{mL})}
$$

After infecting the bacterial culture with the phage at MOI 1, $100 \mu \mathrm{L}$ aliquots were withdrawn from the falcon tube containing mixture at various time points $(0,10,20,30$, $45,60,90,120$, and $180 \mathrm{~min}$ ), where they were serially diluted and spotted on the plate containing the bacterial host in lawn (double-layered) top agar to enumerate the phage particles released from the infected bacterial cells over the time while chloroform was added to the other sample at a concentration of $1 \%(v / v)$ to release the intracellular phages to determine the eclipse period, then all plates were incubated overnight at $37^{\circ} \mathrm{C}$.

\subsection{Time-Killing Curves}

To investigate the antibacterial effect of phage ZCSE6 as described in [24], host bacterial cultures at an optical density at $600 \mathrm{~nm}\left(\mathrm{OD}_{600}\right)$ of 0.4 , which is equivalent to $10^{8} \mathrm{CFU} / \mathrm{mL}$, were infected with phage at different MOIs $(0.1,0.01$, and 0.001$)$ and incubated at $37^{\circ} \mathrm{C}$ for $7 \mathrm{~h}$. During the incubation time, the absorbance changes at $600 \mathrm{~nm}\left(\mathrm{OD}_{600}\right)$ were measured using Jenway 7200 visible spectrophotometer (Jenway, Staffordshire, UK) at various time points $(0,15,40,60,75,90,120,165,195,225,360,390$, and $420 \mathrm{~min})$. 


\subsection{Phage ZCSE6 Activity at Low Temperature}

The antimicrobial effect of phage ZCSE6 was also explored at low temperature by mixing the phage $\left(10^{6} \mathrm{PFU} / \mathrm{mL}\right)$ with Salmonella $\left(10^{6} \mathrm{CFU} / \mathrm{mL}\right)$ at MOI of 1 at $8{ }^{\circ} \mathrm{C}$. Following incubation at $8{ }^{\circ} \mathrm{C}$, various samples were withdrawn after 4 and $24 \mathrm{~h}$ to quantify the number of bacterial survivors $(\mathrm{CFU} / \mathrm{mL})$ using a spotting assay as previously described.

\subsection{Determination of the Phage Stability and Lytic Activity in Milk}

The activity of phage ZCSE6 in raw milk was investigated by sterilizing the raw milk through exposing it directly to a high temperature $\left(110^{\circ} \mathrm{C}, 20 \mathrm{~min}\right)$ and UV $(253 \mathrm{~nm}$, $15 \mathrm{~min}$ ), to omit any source of contamination. Sterile test tubes were filled with $5 \mathrm{~mL}$ of milk inoculated with Salmonella $\left(5 \times 10^{6} \mathrm{CFU} / \mathrm{mL}\right)$. Then, the control and bacteria treated with phage at MOI equal to 2 were incubated at $37^{\circ} \mathrm{C}$ with shaking for $3 \mathrm{~h}$. Aliquots of $100 \mu \mathrm{L}$ were withdrawn and serially diluted to enumerate the bacterial count in CFU after 0, 90, and $180 \mathrm{~min}$. Phage titer $(\mathrm{PFU} / \mathrm{mL})$ was determined before and after the incubation.

The bacterial survival at other temperatures, including $25^{\circ} \mathrm{C}$ and $4{ }^{\circ} \mathrm{C}$ for 4 and $24 \mathrm{~h}$, were tested by adding the phage with titer $\sim 5 \times 10^{6} \mathrm{PFU} / \mathrm{mL}$ as a final concentration in $5 \mathrm{ml}$ of raw milk. In addition, another experiment was conducted to test the stability of the phage with titer $\sim 5 \times 10^{6} \mathrm{PFU} / \mathrm{ml}$ as a final concentration in $5 \mathrm{ml}$ of milk at the low temperature of $4{ }^{\circ} \mathrm{C}$ without adding any bacteria over 6 days.

\section{Conclusions}

In conclusion, this study provides information about the isolation and characterization of novel phages from milk. Phage ZCSE6 is found to be a potential antibacterial agent against Salmonella bacteria. The lytic activity of the phage was confirmed under different industrial conditions and bacterial concentrations. Therefore, phage ZCSE6 is strongly recommended as a milk preservative to control Salmonella contamination. Further studies are needed to testify the biocontrol ability of ZCSE6 under wider manufacturing conditions and to test its lysis ability in other Salmonella-infected food products.

Supplementary Materials: The following are available online at https:/ / www.mdpi.com/article/10 $.3390 /$ biologics1020010/s1. Table S1: The host range for ZCSE6 phage against a variety of Salmonella enterica strains

Author Contributions: Conceptualization, A.S.A. and A.S.; methodology, A.S.A., R.N., A.E. and A.S.; validation, A.S.A.; formal analysis, A.S.A.; writing—original draft preparation, S.M.; supervision, A.E.-S.; funding acquisition, A.E.-S. All authors have read and agreed to the published version of the manuscript.

Funding: This research was funded by the Academy of Scientific Research and Technology (ASRT), Genetic call (51/2020), and Zewail City of Science and Technology internal grant No. ZC 019-2019.

Data Availability Statement: No new data were created or analyzed in this study. Data sharing is not applicable to this article.

Acknowledgments: Many thanks to Alyaa Dawoud, and Kareem Essam for their help. The authors thank Philip J. Richards for the critical evaluation of the manuscript's English language.

Conflicts of Interest: The authors declare no conflict of interest.

\section{References}

1. Faille, C.; Cunault, C.; Dubois, T.; Benezech, T. Hygienic design of food processing lines to mitigate the risk of bacterial food contamination with respect to environmental concerns. Innov. Food Sci. Emerg. Technol. 2018. [CrossRef]

2. O'Sullivan, L.; Bolton, D.; McAuliffe, O.; Coffey, A. The use of bacteriophages to control and detect pathogens in the dairy industry. Int. J. Dairy Technol. 2020, 73, 1-11. [CrossRef]

3. Bao, H.; Zhang, P.; Zhang, H.; Zhou, Y.; Zhang, L.; Wang, R. Bio-control of Salmonella Enteritidis in foods using bacteriophages. Viruses 2015, 7, 4836-4853. [CrossRef]

4. Afshari, A.; Baratpour, A.; Khanzade, S.; Jamshidi, A. Salmonella enteritidis and Salmonella typhimorium identification in poultry carcasses. Iran. J. Microbiol. 2018, 10, 45-50. 
5. Abd El-Tawab, A.; Elhalim, A.; Hegazy, M. Bacteriological and molecular studies on Salmonella species isolated from poultry farms. Benha Vet. Med J. 2019, 36, 280-293. [CrossRef]

6. El-Sharkawy, H.; Tahoun, A.; El-Gohary, A.E.G.A.; El-Abasy, M.; El-Khayat, F.; Gillespie, T.; Kitade, Y.; Hafez, H.M.; Neubauer, H.; El-Adawy, H. Epidemiological, molecular characterization and antibiotic resistance of Salmonella Enterica serovars isolated from chicken farms in Egypt. Gut Pathog. 2017, 9. [CrossRef] [PubMed]

7. Andrés Barranco, S.; Vico, J.P.; Grilló, M.J.; Mainar Jaime, R.C. Reduction of subclinical S almonella infection in fattening pigs after dietary supplementation with a ß-galactomannan oligosaccharide. J. Appl. Microbiol. 2015, 118, 284-294. [CrossRef] [PubMed]

8. Cavallo, S.J.; Daly, E.R.; Seiferth, J.; Nadeau, A.M.; Mahoney, J.; Finnigan, J.; Wikoff, P.; Kiebler, C.A.; Simmons, L. Human outbreak of Salmonella Typhimurium associated with exposure to locally made chicken jerky pet treats, New Hampshire, 2013. Foodborne Pathog. Dis. 2015, 12, 441-446. [CrossRef] [PubMed]

9. Carrasco, E.; Morales-Rueda, A.; García-Gimeno, R.M. Cross-contamination and recontamination by Salmonella in foods: A review. Food Res. Int. 2012, 45, 545-556. [CrossRef]

10. El-Shibiny, A.; Dawoud, A. Bacteriophage applications for food safety. In Biocommunication of Phages; Witzany, G., Ed.; Springer International Publishing: Cham, Switzerland, 2020; pp. 463-484, ISBN 9783030458850.

11. Soares, V.M.; Pereira, J.G.; Viana, C.; Izidoro, T.B.; dos SantosBersot, L.; de Almeida NogueiraPinto, J.P. Transfer of Salmonella Enteritidis to four types of surfaces after cleaning procedures and cross-contamination to tomatoes. Food Microbiol. 2012, 30, 453-456. [CrossRef] [PubMed]

12. Soto, M.J.; Retamales, J.; Palza, H.; Bastías, R. Encapsulation of specific Salmonella Enteritidis phage f $3 \alpha \mathrm{SE}$ on alginate-spheres as a method for protection and dosification. Electron. J. Biotechnol. 2018. [CrossRef]

13. Sillankorva, S.M.; Oliveira, H.; Azeredo, J. Bacteriophages and their role in food safety. Int. J. Microbiol. 2012. [CrossRef]

14. Mahony, J.; McAuliffe, O.; Ross, R.P.; van Sinderen, D. Bacteriophages as biocontrol agents of food pathogens. Curr. Opin. Biotechnol. 2011, 22, 157-163. [CrossRef] [PubMed]

15. Atterbury, R.J.; Van Bergen, M.A.P.; Ortiz, F.; Lovell, M.A.; Harris, J.A.; De Boer, A.; Wagenaar, J.A.; Allen, V.M.; Barrow, P.A. Bacteriophage therapy to reduce Salmonella colonization of broiler chickens. Appl. Environ. Microbiol. 2007, 73, 4543-4549. [CrossRef] [PubMed]

16. Jo czyk-Matysiak, E.N.; Kula, D.; Owczarek, B.; Orwat, F.; Mi dzybrodzki, R.; Neuberg, J.; Bagi ska, N.; Weber-D browska, B.; Gńrski, A. Factors determining phage stability/activity: Challenges in practical phage application. Expert Rev. Anti. Infect. Ther. 2019, 17, 583-606. [CrossRef] [PubMed]

17. Hungaro, H.M.; Mendonça, R.C.S.; Gouvêa, D.M.; Vanetti, M.C.D.; de OliveiraPinto, C.L. Use of bacteriophages to reduce Salmonella in chicken skin in comparison with chemical agents. Food Res. Int. 2013, 52, 75-81. [CrossRef]

18. Huang, C.; Virk, S.M.; Shi, J.; Zhou, Y.; Willias, S.P.; Morsy, M.K.; Abdelnabby, H.E.; Liu, J.; Wang, X.; Li, J. Isolation, characterization, and application of bacteriophage LPSE1 against Salmonella enterica in ready to eat (RTE) foods. Front. Microbiol. 2018, 9 , 1046. [CrossRef] [PubMed]

19. Capparelli, R.; Nocerino, N.; Iannaccone, M.; Ercolini, D.; Parlato, M.; Chiara, M.; Iannelli, D. Bacteriophage therapy of Salmonella enterica: A fresh appraisal of bacteriophage therapy. J. Infect. Dis. 2010, 201, 52-61. [CrossRef]

20. Dallal, M.M.S.; Nikkhahi, F.; Alimohammadi, M.; Douraghi, M.; Rajabi, Z.; Foroushani, A.R.; Azimi, A.; Fardsanei, F. Phage therapy as an approach to control Salmonella enterica serotype Enteritidis infection in mice. Rev. Soc. Bras. Med. Trop. 2019, 52 [CrossRef]

21. Gao, R.; Naushad, S.; Moineau, S.; Levesque, R.; Goodridge, L.; Ogunremi, D. Comparative genomic analysis of 142 bacteriophages infecting Salmonella enterica subsp. enterica. BMC Genomics 2020, 21, 1-13. [CrossRef]

22. Shin, H.; Lee, J.-H.; Kim, H.; Choi, Y.; Heu, S.; Ryu, S. Receptor diversity and host interaction of bacteriophages infecting Salmonella enterica serovar Typhimurium. PLoS ONE 2012. [CrossRef]

23. Nikkhahi, F.; Dallal, M.M.S.; Alimohammadi, M.; Foroushani, A.R.; Rajabi, Z.; Fardsanei, F.; Imeni, S.M.; Bonab, P.T. Phage therapy: Assessment of the efficacy of a bacteriophage isolated in the treatment of salmonellosis induced by Salmonella Enteritidis in mice. Gastroenterol. Hepatol. Bed Bench 2017, 10, 131.

24. Abdelsattar, A.S.; Nofal, R.; Makky, S.; Safwat, A.; Taha, A.; El-Shibiny, A. The Synergistic Effect of Biosynthesized Silver Nanoparticles and Phage ZCSE2 as a Novel Approach to Combat Multidrug-Resistant Salmonella enterica. Antibiotics 2021, 10, 678. [CrossRef]

25. Lim, T.-H.; Kim, M.-S.; Lee, D.-H.; Lee, Y.-N.; Park, J.-K.; Youn, H.-N.; Lee, H.-J.; Yang, S.-Y.; Cho, Y.-W.; Lee, J.-B. Use of bacteriophage for biological control of Salmonella Enteritidis infection in chicken. Res. Vet. Sci. 2012, 93, 1173-1178. [CrossRef]

26. Phongtang, W.; Choi, G.-P.; Chukeatirote, E.; Ahn, J. Bacteriophage control of Salmonella Typhimurium in milk. Food Sci. Biotechnol. 2019, 28, 297-301. [CrossRef]

27. Mobarki, N.; Almerabi, B.; Hattan, A. Antibiotic Resistance Crisis. Int. J. Med. Dev. Ctries. 2019, 3, 561-564. [CrossRef]

28. Mohamed, A.; Taha, O.; El-Sherif, H.M.; Connerton, P.L.; Hooton, S.P.T.; Bassim, N.D.; Connerton, I.F.; El-Shibiny, A. Bacteriophage ZCSE2 is a Potent Antimicrobial against Salmonella enterica Serovars: Ultrastructure, genomics and efficacy. Viruses 2020, 12, 424. [CrossRef]

29. McCallin, S.; Sacher, J.C.; Zheng, J.; Chan, B.K. Current state of compassionate phage therapy. Viruses 2019, 11, 343. [CrossRef]

30. Amarillas, L.; Cháidez-Quiroz, C.; Sañudo-Barajas, A.; León-Félix, J. Complete genome sequence of a polyvalent bacteriophage, phiKP26, active on Salmonella and Escherichia coli. Arch. Virol. 2013, 158, 2395-2398. [CrossRef] 
31. Abdelsattar, A.S.; Dawoud, A.; Makky, S.; Nofal, R.; Aziz, R.K.; El-Shibiny, A. Bacteriophages: From isolation to application. Curr. Pharm. Biotechnol. 2021. [CrossRef]

32. Loc-Carrillo, C.; Abedon, S.T. Pros and cons of phage therapy. Bacteriophage 2011, 1, 111-114. [CrossRef]

33. Jurczak-Kurek, A.; Gsior, T.; Nejman-Fale czyk, B.; Bloch, S.; Dydecka, A.; Topka, G.; Necel, A.; Jakubowska-Deredas, M.; Narajczyk, M.; Richert, M. Biodiversity of bacteriophages: Morphological and biological properties of a large group of phages isolated from urban sewage. Sci. Rep. 2016, 6, 1-17. [CrossRef]

34. Gwak, K.M.; Choi, I.Y.; Lee, J.; Oh, J.-H.; Park, M.-K. Isolation and characterization of a lytic and highly specific phage against Yersinia enterocolitica as a novel biocontrol agent. J. Microbiol. Biotechnol. 2018, 28, 1946-1954. [CrossRef] [PubMed]

35. Chang, Y.; Bai, J.; Lee, J.H.; Ryu, S. Mutation of a Staphylococcus aureus temperate bacteriophage to a virulent one and evaluation of its application. Food Microbiol. 2019. [CrossRef]

36. El-Shibiny, A.; El-Sahhar, S.; Adel, M. Phage applications for improving food safety and infection control in Egypt. J. Appl. Microbiol. 2017, 123, 556-567. [CrossRef] [PubMed]

37. Abdelsattar, A.S.; Abdelrahman, F.; Dawoud, A.; Connerton, I.F.; El-Shibiny, A. Encapsulation of E. coli phage ZCEC5 in chitosan-alginate beads as a delivery system in phage therapy. AMB Express 2019, 9, 87. [CrossRef]

38. Bochkareva, S.S.; Karaulov, A.V.; Aleshkin, A.V.; Novikova, L.I.; Kiseleva, I.A.; Rubal'skii, E.O.; Mekhtiev, E.R.; Styshnev, A.O.; Zul'karneev, E.R.; Anurova, M.N. Analysis of the Pharmacokinetics of Suppository Forms of Bacteriophages. Bull. Exp. Biol. Med. 2020, 168, 748-752. [CrossRef] [PubMed]

39. Parada, V.; Herndl, G.J.; Weinbauer, M.G. Viral burst size of heterotrophic prokaryotes in aquatic systems. J. Mar. Biol. Assoc. UK 2006, 86, 613-621. [CrossRef]

40. Gao, Y.; Liu, Q.; Wang, M.; Zhao, G.; Jiang, Y.; Malin, G.; Gong, Z.; Meng, X.; Liu, Z.; Lin, T. Characterization and genome sequence of marine Alteromonas gracilis phage PB15 isolated from the Yellow Sea, China. Curr. Microbiol. 2017, 74, 821-826. [CrossRef]

41. Zhang, X.; Liu, Y.; Wang, M.; Wang, M.; Jiang, T.; Sun, J.; Gao, C.; Jiang, Y.; Guo, C.; Shao, H. Characterization and genome analysis of a novel marine Alteromonas phage P24. Curr. Microbiol. 2020, 77, 2813-2820. [CrossRef]

42. Styles, K.M.; Thummeepak, R.; Leungtongkam, U.; Smith, S.E.; Christie, G.S.; Millard, A.; Moat, J.; Dowson, C.G.; Wellington, E.M.H.; Sitthisak, S. Investigating bacteriophages targeting the opportunistic pathogen Acinetobacter baumannii. Antibiotics 2020, 9, 200. [CrossRef] [PubMed]

43. Jeon, J.; Park, J.-H.; Yong, D. Efficacy of bacteriophage treatment against carbapenem-resistant Acinetobacter baumannii in Galleria mellonella larvae and a mouse model of acute pneumonia. BMC Microbiol. 2019, 19, 70. [CrossRef] [PubMed]

44. Imam, M.; Alrashid, B.; Patel, F.; Dowah, A.S.A.; Brown, N.; Millard, A.; Clokie, M.R.J.; Galyov, E.E. vB_PaeM_MIJ3, a novel jumbo phage infecting Pseudomonas aeruginosa, possesses unusual genomic features. Front. Microbiol. 2019, 10, 2772. [CrossRef] [PubMed]

45. Jansen, M.; Wahida, A.; Latz, S.; Krüttgen, A.; Häfner, H.; Buhl, E.M.; Ritter, K.; Horz, H.-P. Enhanced antibacterial effect of the novel T4-like bacteriophage KARL-1 in combination with antibiotics against multi-drug resistant Acinetobacter baumannii. Sci. Rep. 2018, 8, 1-12. [CrossRef]

46. Liu, J.; Gao, S.; Dong, Y.; Lu, C.; Liu, Y. Isolation and characterization of bacteriophages against virulent Aeromonas hydrophila. BMC Microbiol. 2020, 20, 1-13. [CrossRef]

47. Tanaka, C.; Yamada, K.; Takeuchi, H.; Inokuchi, Y.; Kashiwagi, A.; Toba, T. A lytic bacteriophage for controlling Pseudomonas lactis in raw cow's milk. Appl. Environ. Microbiol. 2018, 84, 18. [CrossRef]

48. Grygorcewicz, B.; Chajęcka-Wierzchowska, W.; Augustyniak, A.; Wasak, A.; Stachurska, X.; Nawrotek, P.; Dołegowska, B. In-milk inactivation of Escherichia coli O157: H7 by the environmental lytic bacteriophage ECPS-6. J. Food Saf. 2020, 40, e12747. [CrossRef]

49. Abdelsattar, A.S.; Dawooud, A.; Rezk, N.; Makky, S.; Safwat, A.; Richards, P.J.; El-Shibiny, A. How to Train Your Phage: The Recent Efforts in Phage Training. Biologics 2021, 1, 70-88. [CrossRef]

50. Yeh, Y.; De Moura, F.H.; Van Den Broek, K.; De Mello, A.S. Effect of ultraviolet light, organic acids, and bacteriophage on Salmonella populations in ground beef. Meat Sci. 2018, 139, 44-48. [CrossRef]

51. Hong, Y.; Schmidt, K.; Marks, D.; Hatter, S.; Marshall, A.; Albino, L.; Ebner, P. Treatment of Salmonella-contaminated eggs and pork with a broad-spectrum, single bacteriophage: Assessment of efficacy and resistance development. Foodborne Pathog. Dis. 2016, 13, 679-688. [CrossRef]

52. Sukumaran, A.T.; Nannapaneni, R.; Kiess, A.; Sharma, C.S. Reduction of Salmonella on chicken meat and chicken skin by combined or sequential application of lytic bacteriophage with chemical antimicrobials. Int. J. Food Microbiol. 2015, $207,8-15$. [CrossRef] [PubMed]

53. Sukumaran, A.T.; Nannapaneni, R.; Kiess, A.; Sharma, C.S. Reduction of Salmonella on chicken breast fillets stored under aerobic or modified atmosphere packaging by the application of lytic bacteriophage preparation SalmoFreshTM. Poult. Sci. 2016, 95, 668-675. [CrossRef] [PubMed]

54. Sarhan, W.A.; Azzazy, H.M.E. Phage approved in food, why not as a therapeutic? Expert Rev. Anti. Infect. Ther. 2015, 13, 91-101. [CrossRef]

55. Kropinski, A.M.; Mazzocco, A.; Waddell, T.E.; Lingohr, E.; Johnson, R.P. Enumeration of bacteriophages by double agar overlay plaque assay. Methods Mol. Biol. 2009, 501, 69-76. [PubMed] 
56. Abdelsattar, A.; El-Shibiny, A. A Modified High-Throughput Screening Protocol to Isolate Bacteriophages from Environmental Samples. Preprints 2021. [CrossRef]

57. Senczek, D.; Stephan, R.; Untermann, F. Pulsed-field gel electrophoresis (PFGE) typing of Listeria strains isolated from a meat processing plant over a 2-year period. Int. J. Food Microbiol. 2000, 62, 155-159. [CrossRef]

58. Taha, O.A.; Connerton, P.L.; Connerton, I.F.; El-Shibiny, A. Bacteriophage ZCKP1: A potential treatment for Klebsiella pneumoniae isolated from diabetic foot patients. Front. Microbiol. 2018, 9, 2127. [CrossRef] 